\title{
PARSE PROBLEMS IN THE APPLICATION OF ACCOUNTING BASED IMFI GRAMEEN
}

\author{
Tri Utami, Fiqih Afriadi \\ Universitas Pamulang \\ gendisutami27@gmail.com
}

\begin{abstract}
The purpose of this study is to reveal various problems application of accounting on Islamic Micro Finance Institutions (IMFI) based grameen. To achieve the study researchers used a methodology Analytical Network Process. Decomposition of the problem conducted by survey-based Grameen IMFI to practitioners as well as in-depth interviews to experts or academicians. Based on the results of the study (decomposition problem) suggests that the problems in the application of accounting-based Grameen IMFI divided into three main clusters, namely the lack of regulation of supporting institutions, the absence of operational standards and minimum operational assistance. The finding of the study suggested that the main problem was on the lack of regulation supporting with the priority number (0.31), followed by problems of lack of operational standards (0.28), and finally the lack of operational assistance (0.14)
\end{abstract}

Keywords: IMFI Accounting, Islamic Micro Finance, Shariah Grameen Mode

\section{INTRODUCTION}

Grameen Bank founded by Muhammad Yunus became an authentic economic phenomenon that even to deliver the Nobel laureate Muhammad Yunus became world peace in 2006. The success of the Grameen Bank makes this model is replicated in various parts of the world, including in Indonesia Grameen replication Indonesia. In the bank experienced a variety of adjustments to customs, local culture and the needs of members and the surrounding environment (Effendi et al., 2018)). Surprisingly, the majority of MFIs based Grameen to continue to grow and be consistent in empowering the poor in Indonesia is the Grameen model of sharia
(Junaedi et al., 2016). Of course being a useful thing to be able to know how this could happen, but something more important than it is to know how the strategies needed in order to effect in alleviating poverty can be maintained and improved. There are many facets that can be dug to see the various causes that make IMFI based Grameen can continue to grow and be consistent in empowering the poor, but there is one side that is relatively easy to understand language that the accounting language is universally understood by all parties. Accounting side is a standardized language, universal, mutually agreed and acceptable by all existing stakeholders. The accounting side also becomes very important if a financial institution wants to 
continue to grow on a large scale. The accounting side will be more vital,

Looking at the phenomenon where IMFI based Grameen in Indonesia continues to experience good growth even to the national level, the application of accounting issues at IMFI is needed to be studied. It is very necessary as a supporter of Grameen-based IMFI development so that growth and development in Indonesia unstoppable IMFI only at the regional level only, but can go national and even international.

But the fact is happening on the ground is there are so many obstacles and problems faced IMFI based Grameen in finance and accounting bookkeeping. From the field of accounting it arises not only from the process of recording transactions to financial reporting, but also appears on the side of the system, the audit, up to the taxation side. From the operational side, the problems that arise are ranging from human resources, limited capital, to the system of governance institutions that are still home to "walk alone" (Irawan et al., 2013).

Obstacles might hinder and burden the course IMFI as an institution. With various limitations, Grameen-based IMFI are often not able to examine and analyze the application of accounting problems at the institution. This study therefore becomes important to be implemented as a material consideration in determining good policy for the management of the Grameen-based IMFI and for society and the government also has an interest in the progress of IMFI-based. The Grameen Bank project was born in the village of Jobra, Bangladesh in 1976. In 1983 it became a special formal bank under a law that was passed for creation. It is owned by poor borrowers from banks who are mostly women. It works specifically for them. Borrowers from Grameen Bank currently own 95 percent of the total equity of the bank. The remaining 5 percent is owned by the government.9 Grameen which means village is used for the name of the bank (Tahkim, n.d.)

State of the art of this study was to unravel the problems of application of accounting at IMFI-based Grameen. Liquidity assistance to the LMS is still relatively limited, it is certainly very much different from the financial institutions that are complete alternatives to the liquidity assistance they receive. The research devoted to alternative liquidity assistance to IMFI-based Grameen still we have not found.

\section{LITERATURE REVIEW}

\subsection{Financial agency is Sharia}

Islamic financial institutions (LKS) is an institution that is based on the Qur'an and Sunnah, as well as on the interpretation of the sources of divine revelation by the scholars. In various forms, the financial structure of Islam has become a civilization that has not changed for fourteen centuries. Over the past three decades, the structure of Islamic finance has emerged as one of the modern implementation of the Islamic legal system's most important and successful, and as a test for the renewal and development of Islamic law. In the future (Vogel, 2007) in (Mughni \& Afriadi, 2019). The progress of LKS obtains to adapt to the needs of society, LKS forms include:

1. Islamic Bank

2. Takaful

3. Islamic pawnshop

4. Islamic capital market

5. BMT and or cooperative sharia

\subsection{Microfinance Institutions Sharia (IMFI)}

Microfinance Institutions (MFIs) are financial institutions and financing founded and owned jointly by good citizens who gathered in community citizens, to solve problems / constraints of capital and financing needs faced by its 
members. MFIs generally aims to pushes economic growth and development of the business community and society in general (Rusydiana \& Devi, 2013).

\section{RESEARCH METHOD}

\subsection{Sources and Types of Data}

This research used the Analytic Network Process (ANP) methods. ANP is the first mathematical theory that makes this method allows us to deal with dependent factors and feedback systematically. In other languages, ANP is one of the multiple criteria decision making (MCDM) methods developed by Thomas L. Saaty. This method is a new approach to the qualitative method which is a continued development of the previous method, Analytic Hierarchy. Process (AHP). The advantage of ANP from other methodologies is its ability to assist us in measuring the synthesis of a number of factors in a hierarchy or network.

The data obtained are of primary data in the form of transcripts of interviews with various respondents then the data is used for processing the ANP method using primary data in the form of questionnaires and secondary data from literature review.

\subsection{Data collection technique}

Research by the ANP has two stage method of data collection. In the early stages, a technique performed for data collection and information is by conducting in-depth interviews / with some respondents. Those respondents are experts / scholars / practitioners who understand the application of accounting on Islamic Financial Institutions.

\subsection{Data analysis technique}

Once the data collected then would be compiled in the form of ANP skeleton model. The results of the questionnaire data have been gathered, the next step is the analyzes of the results that have been obtained. This analytical tool used was ANP and processed using the software "SuperDecision" which can be obtained from http://www.superdecision.com

\subsection{Runway ANP}

ANP has three axioms which form the basis of his theory (Ascarya, 2005): The third axiom is:

1) Reciprocal.

This axiom states that if a PC (EA, EB) is the value of comparing pairs of elements $\mathrm{A}$ and $\mathrm{B}$, seen from its parent element $\mathrm{C}$, which indicates how many times more elements of $\mathrm{A}$ have the what possessed elements of $\mathrm{B}$, then the PC (EB, EA): 1 / PC (EA, AB). For example, if a five times greater than $B$, then $\mathrm{B}$ is a large amount of $1 / 5$ of $\mathrm{A}$.

\section{2) Homogeneity.}

This axiom states that the elements compared should not have too big difference, which can cause greater judgments errors. The scale used in AHP and ANP is a verbal scale are converted into a numerical scale of 1 to 9 (see Table 3.1). Axiom that those who have reason to belief should ensure that their ideas are adequately represented in the results to match expectations. (Saaty, 2006)

\section{RESULTS AND DISCUSSION \\ 4.1 Identification and Decomposition Problems}

Based on the results of the study (decomposition problem) suggests that the problems in the application of accountingbased Grameen IMFI divided into three main clusters, namely the lack of regulation of supporting institutions, the absence of operational standards and minimum operational assistance. The results of questionnaires comparison of the respondents were as follows 

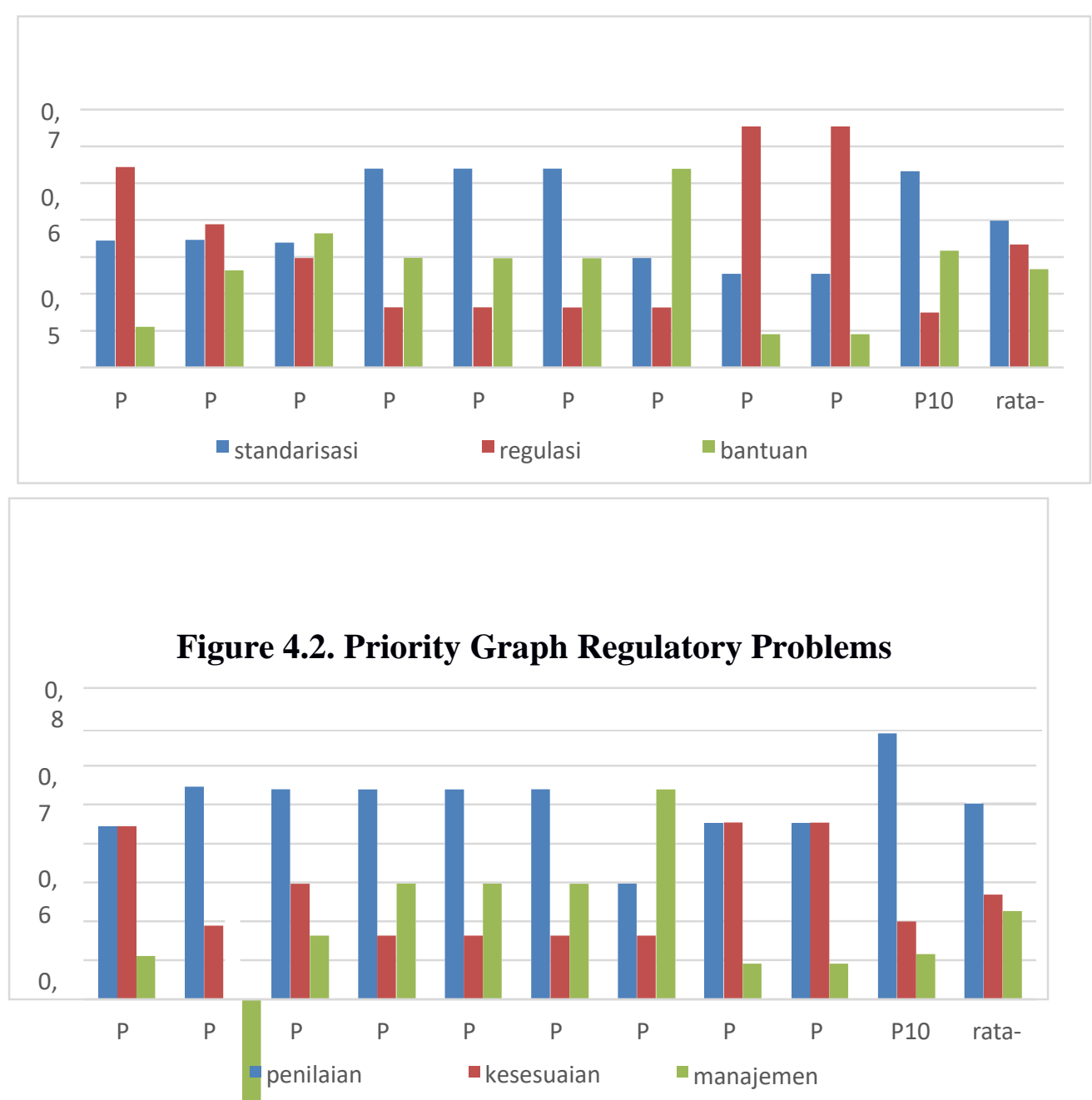

From the above chart can be seen that the problem of lack of standard operating a major problem with the priority number (0.41), followed by supporting regulation (0.33), and finally the lack of operational assistance (0.26) Further problems associated decomposition Cluster problem is not lack of regulation support consists of three elements of risk management, health assessment and suitability sharia. Clusters second problem is the lack of standard operating with three elements namely the financial recording and reporting standards, audit standards and standards-based Grameen IMFI accounting system. And the last problem clusters namely the lack of operational assistance to the three elements that help the development of human resources, capital support and help of information technology. Describe in more detail in the following points:

\subsubsection{The existence yet Regulatory Support}

Islamic microfinance institutions (IMFI) based Grameen has the liquidity risk are particularly vulnerable since most members or The dominant clients of micro-small. In certain seasons such as every new school year or religious holidays such as Idul Fitri and Idul Adha, the liquidity risk to be increased in view of many members and customers to withdraw their funds almost simultaneously (Sakti, 2013).

Standard analysis of financing and risk management is important to be held. Financing problems stems from errors 
due diligence practices of business(Karsidi et al., 2018) Operational projection error factor proved to be quite prominent in the troubled liquidity Islamic microfinance institutions (IMFI) based Grameen (Sakti, 2013). Factors honesty of customers and partners work Islamic microfinance institutions (IMFI) based Grameen has also become one of the obstacles, particularly on products for results-based financing; such as mudaraba financing and Musharaka (Hamzah et al., 2013).

The fundamental difference between Islamic microfinance institutions (IMFI) based Grameen with other MFIs located on its services in accordance with Islamic principles. Thus, it is supposed to be a benchmark of professionalism of the practitioners of Islamic microfinance institutions (IMFI) based Grameen is in terms of mastery of the concept of shari'a finance, both theoretically and practically (Karsidi et al., 2018).

Islamic microfinance institutions (IMFI) Grameen-based financial as an intitution relatively close and thus relies on public trust, should be conducted with caution because it has risk high (Imaniyati, 2004). The absence of regulatory risk management specific customer funds for Islamic microfinance institutions (IMFI) based Grameen be an obstacle in optimizing the collection (D. Hascaryani et al., 2011). This then resulted in MFI service coverage is still not able to reach out broadly. Among the institutions needed to overcome this is to ensure the guarantee institution MFI loan or guarantee funds in IMFI (Sutrisno, 2005). (Kusmuljono, 2009) also suggested that established Apex Islamic microfinance institutions (IMFI) -based umbrella Grameen microfinance institutions. The results of questionnaires comparison of the respondents were as follows:
From the above chart can be seen that in the absence of regulatory support cluster, the regulation of the health assessment is a top priority primarily to the priority value of 0.45 . Ranked in priority to two, namely Sharia regulation conformity with the value of 0.29 and last priority is regulatory risk management with a priority value of 0.26 .

\subsubsection{Not to existence Operational Standards Implementation of Accounting}

Hamzah et al., (2013) in his research concluded that external issues occupy the highest priority on the development of IMFI is the absence of specific regulations governing the application of accounting at IMFI. In fact, IMFI requires effective regulation and supervision both of financial management and suitability to the sharia. To avoid a loss to the community as customers, should only IMFI healthy and well supervised allowed to raise funds from non-members (Seibel, 2008).

In addition to the application of accounting at a financial institution is something that must be done as part of the oversight function of the existing authorities (Nugroho et al, 2008). The operational application of accounting standards is also indispensable as one of the main strategies improve business IMFI (Jansson et al., 2004). This operational standard is also needed once by practitioners associated IMFI specific mechanisms to overcome the problems of application of accounting IMFI specialized in Java alternative application of accounting has been quite varied ranging from manual, excel professional, a professional accountant to use accounting software (Sakti, 2013). However, the standard uniform, reliable and can be used as a common reference still exists today.

From the above chart can be seen that in the absence of the cluster

\footnotetext{
* Corresponding author's e-mail: gendisutami27@gmail.com

http://openjournal.unpam.ac.id/index.php/EAJ
} 
operational standards, the problem is not the financial recording and reporting standards is a top priority primarily to the priority value of 0.39 . Ranked in priority to two with the difference that is notmuch that the problem is not lack of standard audit standards with the value of 0.35 and last priority is standards-based Grameen IMFI accounting system with a priority value of 0.26 .

\subsubsection{Not to adequacy of Operational Support}

One of the main obstacles faced by administrators in the management of Islamic microfinance institutions (IMFI) based Grameen is a problem capital (Sakti, 2013)

Other studies such as Sutrisno (2005) also stated the same thing. Managerial coaching and human resources development is also a problem that many face on Islamic microfinance institutions (IMFI) based Grameen. It is just as concluded from the study Hamzah et al (2013) which states that personnel problem was an internal matter who occupied the highest priority. Research (Sakti, 2013) and (Sutrisno, 2005) also concluded that one of them is also quite prominent obstacles faced by administrators of Islamic microfinance institutions (IMFI) based Grameen is a matter of competence SDM3. In addition, other internal problems faced by the Islamic microfinance institutions (IMFI) based Grameen is a lack of managerial ability (Sutrisno, 2005) the lack of IT facilities, and a lack of product innovation (Hamzah et al., 2013).

The results of questionnaires comparison of the respondents were as follows: From the above chart can be seen that the lack of operational support cluster, the problem of minimal help Human Resources Empowerment is a top priority with a priority value of 0.39 . Ranking second and third priority is the problem of the lack of Information Technology Assistance with a priority value of 0.34 and
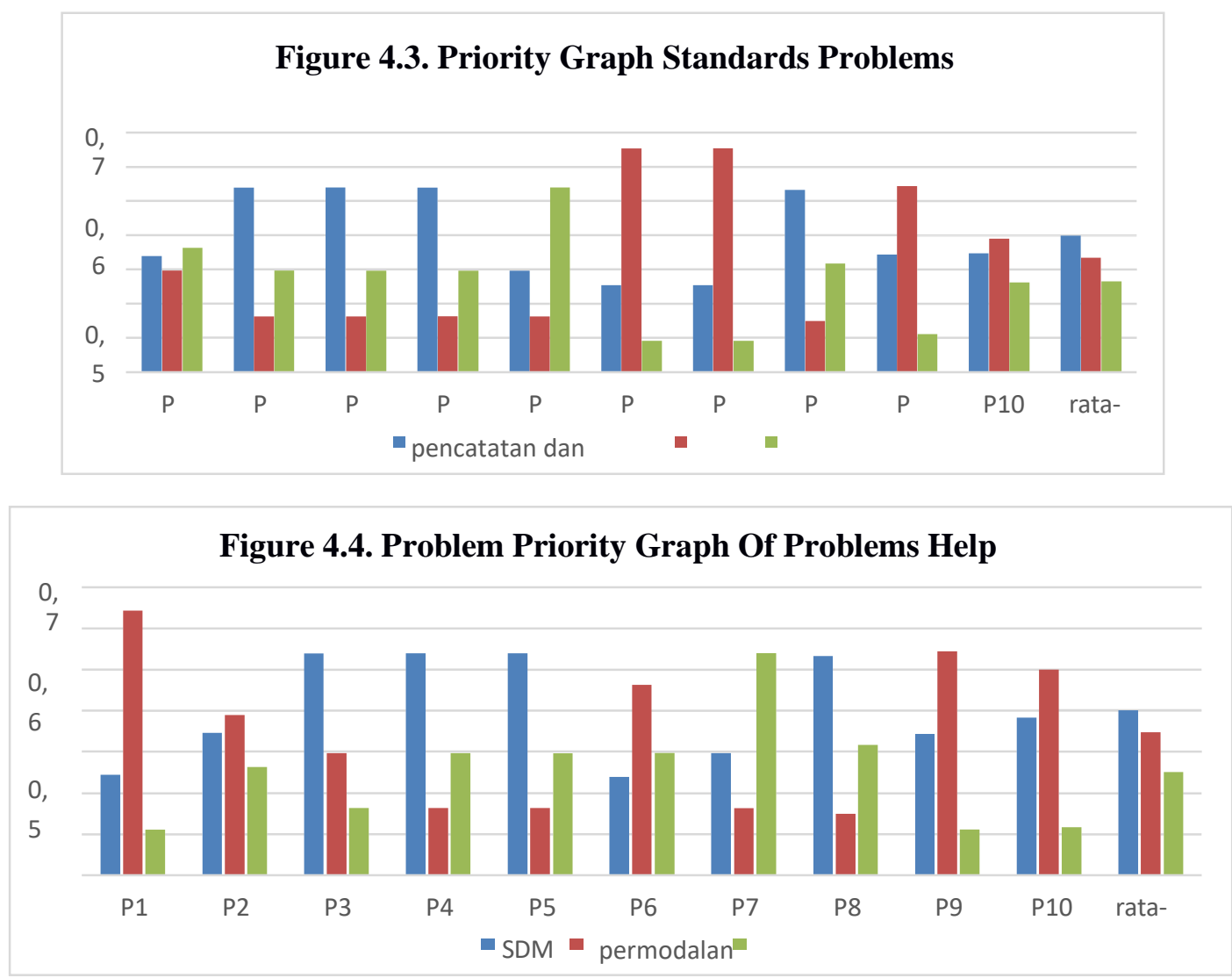

* Corresponding author's e-mail: gendisutami27@gmail.com 
the third priority order that limited capital fund with a priority value of 0.27 .

\section{CONCLUSIONS}

Based on the discussion and analysis of development issues IMFI terms of regulation and institutions, following a number of conclusions regarding this discussion, are as follows:

1. Based on the results of the study (decomposition problem) suggests that the problems in the application of accounting-based Grameen IMFI divided into three main clusters, namely the lack of regulation of supporting institutions, the absence of operational standards and minimum operational assistance. Cluster support problem is not lack of regulation consists of three elements of risk management, health assessment and suitability sharia, Risk Management cycle must be implemented as well. Clusters second problem is the lack of standard operating with three elements namely the financial recording and reporting standards, audit standards and standards-based Grameen IMFI accounting system such as (Standard Operating Procedure/SOP is required to make their operations done properly). And the last problem clusters namely the lack of operational assistance to the three elements that help the development of human resources, capital support and help of information technology. Financial Institution/FI transactions is complex and using a lot of instruments, so beside technology they also need good monitoring and reconciliation.

2. The problem is not the problem of the lack of standard operating a major problem with the priority number (0.41), followed by supporting regulation (0.33), and finally the lack of operational assistance (0.26) In the absence of regulation of cluster support, regulatory support through health assessment is a top priority primarily to the priority value of 0.45 . Ranked in priority to two, namely Sharia regulation conformity with the value of 0.29 and last priority is regulatory risk management with a priority value of 0.26 .

3 . In the absence of the cluster operational standards, the problem is not the financial recording and reporting standards is a top priority primarily to the priority value of 0.39 . Ranked in priority to two with the difference that is not much that the problem is not lack of a standard audit standard with the value of 0.35 and last priority is standards-based Grameen IMFI accounting system with a priority value of 0.26 .

4. In cluster lack of operational assistance, the problem of minimal help Human Resources Empowerment is a top priority with a priority value of 0.39 . Ranking second and third priority is the problem of the lack of Information Technology Assistance with a priority value of 0.34 and the third priority order that limited capital fund with a priority value of 0.27 .

\section{REFERENCES}

Ascarya. (2005). Analytic Network Process (ANP): Pendekatan Baru Studi Kualitatif. Center for Central Banking Education and Studies, Bank Indonesia.

D. Hascaryani, T., Manzilati, A., \& S. Fadjar, N. (2011). Metafora Risk and Return Sebagai Dasar Pengembangan 
Baitul Maal Wa Tamwil (Bmt) Yang Mandiri. Journal of Indonesian Applied Economics, 5(1), 1-2011. https://doi.org/10.21776/ub.jiae.2011. 005.01.3

Effendi, J., Baga, L. M., Beik, I. S., \& Nursyamsiah, T. (2018). Aplikasi Model Bisnis Microbanking Syariah Di Indonesia. Iqtishadia, 10(2), 120. https://doi.org/10.21043/iqtishadia.v1 $0 \mathrm{i} 2.2241$

Hamzah, D., Rusby, D. Z., \& Hamzah, Z. (2013). Analysis Problem of Baitul Maal Wat Tamwil (BMT) Operation in Pekanbaru Indonesia Using Analytical Network Process (ANP) Approach. International Journal of Academic Research in Business and Social Sciences, 3(8), 215-228. https://doi.org/10.6007/ijarbss/v3i8/138

Hidayat, A., Friska, Y., Anggraini, A., Syafi'i, M. T., \& Kusumaningsih, A. (2019). Peningkatan Keterampilan Dasar Matematika dan Bahasa Inggris Sebagai Upaya dalam Menghadapi Tantangan Era Revolusi Industri 5.0. Abdimisi, 1(1), 55-62.

Hidayat, A., \& Sadewa, P. (2020). Pengaruh Penggunaan Aplikasi Eviews Terhadap Sikap Belajar dan Kemampuan Pemecahan Masalah Statistik. Edumaspul: Jurnal Pendidikan, 4(1), 321-328.

Irawan, D., Affandi, M., \& Kalsum, U. (2013). Analisis Strategi Pengembangan Lembaga Keuangan Mikro Syariah (Lkms) Pedesaan (Studi Kasus Bmt Al Hasanah Sekampung). Jurnal Ilmu-Ilmu Agribisnis, 1(1), 13395.

Jansson, T., Rosales, R., \& Westley, G. D. (2004). Principles and Practices for Regulating and Supervising Microfinance. In Sustainable Development.

Junaedi, D., Huda, N., Wiliasih, R., \& Irianto, S. G. (2016). Studi Komparasi Kinerja Pengembangan Usaha Agribisnis Perdesaan Syariah dan
Konvensional di Jawa Tengah. Jurnal Agro Ekonomi. https://doi.org/10.21082/jae.v30n2.20 12.183-199

Karsidi, Rahab, \& Mustofa, R. M. (2018). Strategi peningkatan profesionalisme praktisi baitul maal wat tamwil (bmt) di kabupaten banyumas. Jurnal Personalia, Financial, Operasional, Marketing Dan Sistem Informasi, 14(2), 13-34.

Kusmuljono, B. S. (2009). Public-private partnership policy: System approach to microfinancing. 53rd Annual Conference of the International Society for the Systems Sciences 2009: Making Liveable, Sustainable Systems Unremarkable.

Mughni, A., \& Afriadi, F. (2019). DEKOMPOSISI PERMASALAHAN DAN SOLUSI KEBIJAKAN PENGEMBANGAN LKMS BERBASIS GRAMEEN. JURNAL AKUNTANSI BERKELANJUTAN INDONESIA.

https://doi.org/10.32493/jabi.v2i1.y20 19.p077-092

Rusydiana, A. S., \& Devi, A. (2013). MENGURAI MASALAH DAN SOLUSI PENGEMBANGAN LEMBAGA KEUANGAN MIKRO SYARIAH DI INDONESIA: PENDEKATAN METODE BOCR

ANP Aam S. Rusydiana. Ekonomi Dan Bisnis Islami, III(1), 19-40.

Saaty, T. L. (2006). The analytic network process. In International Series in Operations Research and Management Science.

Sakti, A. (2013). PEMETAAN KONDISI DAN POTENSI BMT: Kemitraan dalam Rangka Memperluas Pasar dan Jangkauan Pelayanan Bank Syariah kepada Usaha Mikro. Al-Muzara'ah. https://doi.org/10.29244/jam.1.1.1-18

Seibel, H. D. (2008). Islamic microfinance in Indonesia: The challenge of institutional diversity, regulation, and supervision. In Sojourn. https://doi.org/10.1355/SJ23-1D 
EAJ (Economics and Accounting Journal) - Vol. 3, No. 2, May 2020 - Utami \& Afriadi

Sutrisno, N. (2005). No Title. Ekonomi Rakyat Usaha Mikro Dan UKM Dalam Perekonomian Indonesia. Jakarta: STEKPI.

Tahkim. (n.d.).

Vogel. (2007). No Title. VOGEL, F. E. Hukum Keuangan Islam: Konsep, Teori Dan Praktik\#Frank E. Vogel (Cet.1.). Bandung: Nusamed.

Undang- undang nomor 1 Tahun 2013 tentang Lembaga Keuangan Mikro (LKM). Undang- undang nomor 17 Tahun 2012 tentang Perkoperasian. 